\title{
Bird community in an Araucaria forest fragment in relation to changes in the surrounding landscape in Southern Brazil
}

\author{
Pedro Scherer-Neto ${ }^{1} \&$ Maria Cecília B. Toledo ${ }^{2}$
}

1. Museu de História Natural Capão da Imbuia, Rua Benedito Conceição, 407, Curitiba, PR, 82810-080, Brazil. (pedroschererneto@yahoo.com.br)
2. Universidade de Taubaté, Departamento de Biologia, Campus Bom Conselho, Av. Tiradentes, 500, Taubaté, SP, 12010-600, Brazil. (cecilia@unitau.br)

\begin{abstract}
The dynamics of the bird community in a small forest fragment was evaluated along seven years in relation to changes in the surrounding landscape. The study area is an Araucaria forest fragment in Southern Brazil (state of Paraná). The sampling period covered the years 1988 through 1994 and the mark-release-recapture method was utilized. The landscape analysis was based on Landsat TM images, and changes in exotic tree plantations, native forest, open areas (agriculture, pasture, bare soil, and abandoned field), and "capoeira" (native vegetation $\leq 2 \mathrm{~m}$ ) were quantified. The relationship between landscape changes and changes in abundance diversity of forest birds, open-area birds, forest-edge birds, and bamboo specialists was evaluated. Richness estimates were run for each year studied. The richness recorded in the study area comprised 96 species. The richness estimates were 114, 118 and 110 species for Chao 1, Jackknife 1 and Bootstrap, respectively. The bird community varied in species richness, abundance and diversity from year to year. As for species diversity, 1991, 1993 and 1994 were significantly different from the other years. Changes in the landscape contributed to the increase in abundance and richness for the groups of forest, open-area and bamboo-specialist species. An important factor discussed was the effect of the flowering of "taquara" (Poaceae), which contributed significantly to increasing richness of bamboo seed eaters, mainly in 1992 and 1993. In general, the results showed that landscape changes affected the dynamics and structure of the bird community of this forest fragment over time, and proved to have an important role in conservation of the avian community in areas of intensive forestry and agricultural activities.
\end{abstract}

KEYWORDS. Richness, abundance, diversity, long-term assessment, state of Paraná.

RESUMO. Comunidade de aves em um fragmento de floresta de araucária em relação a mudanças na paisagem circundante no sul do Brasil. Este estudo avaliou a dinâmica da comunidade de aves em um fragmento florestal ao longo de sete anos e correlacionou às mudanças ocorridas na paisagem circundante. A área de estudo localiza-se na Região Sul do Brasil (Estado do Paraná) e a vegetação está representada por Floresta Ombrófila Mista. O período de amostragem ocorreu entre os anos de 1988 a 1994 e o método utilizado foi captura-marcação e recaptura. Para análise da mudança no uso e cobertura da paisagem foram utilizadas imagens Landsat TM e um sistema de informação geográfico. Quatro classes foram usadas, sendo: plantios com espécies exóticas, floresta nativa, capoeiras (vegetação nativa $<2 \mathrm{~m}$ de altura) e áreas abertas (campo abandonado, pastagens, área agrícola e solo exposto). Foi analisada a relação entre as mudanças na paisagem e as mudanças na abundância e diversidade de aves de floresta, de área aberta, de borda e especialistas de bambu. Foram calculadas as estimativas de riqueza para cada ano estudado. A riqueza registrada na área de estudo foi de 96 espécies e as estimativas foram 114, 118 e 110 espécies para Chao 1, Jackknife 1 e Bootstrap, respectivamente. A comunidade de aves variou em abundância, riqueza e diversidade entre os anos estudados. Considerando a diversidade de espécies, os valores observados em 1991, 1993 e 1994 foram significativamente diferentes. As modificações na paisagem também contribuíram para o aumento da abundância e riqueza de espécies dos grupos: floresta, área aberta e especialistas de bambu. Um fator importante discutido foi o efeito da floração da taquara (Poaceae), que contribuiu para o aumento significativo da riqueza de aves especializadas em comer sementes de bambu, principalmente em 1992 e 1993. Em geral, observou-se que as modificações na paisagem afetaram a dinâmica e estrutura da comunidade de aves do fragmento florestal ao longo do tempo, evidenciando que até mesmo um fragmento pequeno pode ter um papel importante na conservação da avifauna em áreas de intensa atividade florestal e agrícola.

PALAVRAS-CHAVE. Riqueza, abundância, diversidade, levantamentos de longo prazo, Estado do Paraná.

The Southeastern region of the state of Paraná, on the western flank of the Serra do Mar, has undergone extensive environmental changes resulting from the development of cities in the Curitiba Metropolitan Area and land use along the plains where the city of Tijucas do Sul is located. Formerly a poor region with lowvalued land, it had tobacco as the main cash crop. In recent decades, small farms were purchased by a forestry company, which started planting exotic trees such as Pinus sp. in large scale. However, isolated fragments of Araucaria Forest remain in the landscape. Today this region has become a mosaic of diverse, highly fragmented phytophysiognomy, characterized by high spatial heterogeneity. According to Lово (2003), between 1985 and 1995, 229,000 hectares of the Araucaria forest were deforested in Paraná. This phytophysiognomy of Atlantic Forest is severely threatened with extinction, and knowledge of the function of these fragments for bird communities is an important conservation tool.
In Brazil, two general approaches are used to study birds in vegetation fragments: (1) local, considering isolated areas of native forests (STRATFORD \& STOUFFER, 1999; Marini, 2001; Maldonado-Coelho \& Marini, 2004); and (2) landscapes, analyzing the dynamics among landscape components (ANJos \& Boçon, 1999; Anjos, 2001, 2007; Ribeiro et al., 2009; MetzGer et al., 2009). Both approaches are used to gather knowledge to support efforts to protect native species. Most studies of bird communities in fragments are spread over different biomes, lack long-term analyses of population dynamics, and are still scarce in view of the enormous Brazilian biodiversity. Studies carried out in fragments of the Amazon Forest in the 1980s and the 1990s have shown that some organisms, mainly birds, have suffered serious population impacts that drove many species to local extinction (STRATFORD \& STOUFFer, 1999; BROOKS et al., 1999), mainly due to low rates of colonization and permanence of birds in the fragments, because of 
both the intrinsic characteristics of the species and the support capacity of the fragments (BIERREGAARD JR. et al., 1992).

The size, level of isolation, shape, and neighboring landscape of a fragment all directly affect its bird community (Turner, 1996; Brooks et al., 1999; Laurence \& Vasconcelos, 2009). Small isolated fragments will probably support low bird diversity. For instance, mixed flocks of understory species have difficulty in moving between native-forest fragments, some species being even unable to cross distances $<100$ m (BierRegaArd JR. \& Lovejoy, 1989). Therefore, the diversity of the bird community in fragments will be balanced by the capacity of each species to move away from a hostile environment (Moore et al., 2008). Some species have a higher capacity for dispersal than others (Johnson \& Gaines, 1990; Wiens, 1994). However, even a single dispersal event between fragments can significantly improve the conservation status of a fragmented population. Therefore, small isolated fragments with secondary vegetation can play a key role in the dispersal process, serving as sleeping, resting and feeding areas (OPDAM, 1991; HAAS, 1995).

In the dynamics of birds versus fragments, some events are unfavorable, such as invasion by opportunistic species or open-area species (LAURANCE et al., 2004). In such cases, the diversity in fragments may, over time, be eroded and their communities come to be dominated by a few species (LAURANCE et al., 2002). In this way, fragments may show a temporal dynamics of species abundance and richness. Understanding this temporal dynamics and determining the real conservation value of small, isolated fragments require long-term research. The effects of fragmentation processes on Brazilian tropical bird communities have been well documented. Data concerns mainly immediate consequences (BIERREGAARD JR. \& Lovejoy, 1989; BierRegaARD JR. \& STOUfFer, 1997; BROOKS et al., 1999; STRATFORD \& StOUfFER, 1999) or are assessments of the communities of old fragments after years of isolation (Anjos, 2001; Ribon et al., 2003; PozzA \& Pires, 2003; Donatelli et al., 2007). Long-term surveys of the Brazilian avifauna are still relatively scarce.

The present study recorded the qualitative and quantitative changes in the bird community of an Araucaria Forest fragment and the surrounding landscape over a seven-year period. Our purpose was to determine the long-term variations in the bird community of a small forest fragment according to changes in the matrix where it is embedded.

\section{MATERIAL AND METHODS}

Study area. This study was carried out in the county of Tijucas do Sul, in Southeastern Paraná (255' $80^{\prime}$ 'S, $49^{\circ} 13^{\prime} 55^{\prime \prime} \mathrm{W} ; 935 \mathrm{~m}$ a.s.1.) and approximately $70 \mathrm{~km}$ South of the capital city, Curitiba (Fig. 1). The climate is subtropical, mesothermal, and humid $(\mathrm{Cfb})$ with heavy frosts and mild summers (IAPAR, 1978). Annual precipitation is $1400 \mathrm{~mm}$ (FERREIRA, 1999). The region is situated within the domain of the Araucaria Forest (Veloso et al., 1991). Most of the primary vegetation has been altered and removed as a result of farming and forest management practices.

The sampling area, the fragment (approximately $15 \mathrm{ha}$ ) and its surroundings, covers approximately 20 ha. The vegetation is classified as Araucaria Forest. LIEBSCH \& ACRA (2004) found 89 plant species belonging to 54 genera of 32 families in another forest fragment less than $20 \mathrm{~km}$ from the study area. The main families of plants in the early successional "capoeira" vegetation of the fragment are Solanaceae (15 species), Asteraceae (14 species), and Melastomataceae (13 species). The fragment is surrounded by plantations of Pinus elliotti and Eucalyptus sp. that are over 15 years old. The understory in the reforested areas was preserved. A side road, along which the mist nets were installed, goes through the study area for about $300 \mathrm{~m}$. One border of the study area is a shallow pond of approximately 0.5 ha, which contains a small island covered by secondgrowth "capoeira" (native vegetation $\leq 2 \mathrm{~m}$ of height). The entire study site is in a rural setting, with tobacco, grain, and root-vegetable crops mixed with native forest fragments and plantations of exotic trees.

Procedures. The sampling period covered the years 1988 through 1994, and 42 two-day-long sampling programs were performed bimonthly. The mark-releaserecapture method was used; and as for marking, it was made with rings provided by the Centro Nacional de Pesquisa e Conservação de Aves Silvestres - CEMAVE. Twenty mist nets were used ( $12 \times 2.5 \mathrm{~m}, 38 \mathrm{~mm}$ mesh) at two sampling sites: one was located at the confluence of different vegetation types inside the fragment, and the other on the border ( $200 \mathrm{~m}$ ) of the fragment and croplands when covered with "capoeira" vegetation and remains of crops. The nets were placed approximately $400 \mathrm{~m}$ apart in pairs or on trails opened in each sampling. The nets were opened at dawn, checked every 20 minutes, and closed at dusk. The sampling months varied from year to year, but in each year samples were taken at least four times, twice in the winter and twice in the summer (Tab. I). Analyses were based on total annual capture data, and recaptures were disregarded. Capture data was used to calculate species richness (Mao Tau), abundance of individuals $(N)$ per species (for both species and family), Shannon-Wiener $\left(\mathrm{H}^{\prime}\right)$, Simpson $(\mathrm{D})$, Evenness $\left(\mathrm{e}^{\mathrm{H} / \mathrm{S}}\right)$, and Equitability $(\mathrm{J})$ indices. Richness data were used to generate the estimates for each year. For this purpose, Chao 1, Jackknife 1 and Bootstrap were run with the Estimates v. 8.2 application tool (Colwell, 2009). In order to compare the community structure over time, the distribution of species according to the abundance rank recorded in each year was tabulated.

In order to compare among annual abundances, one-way ANOVA $(F)$ was used, with a significance level 


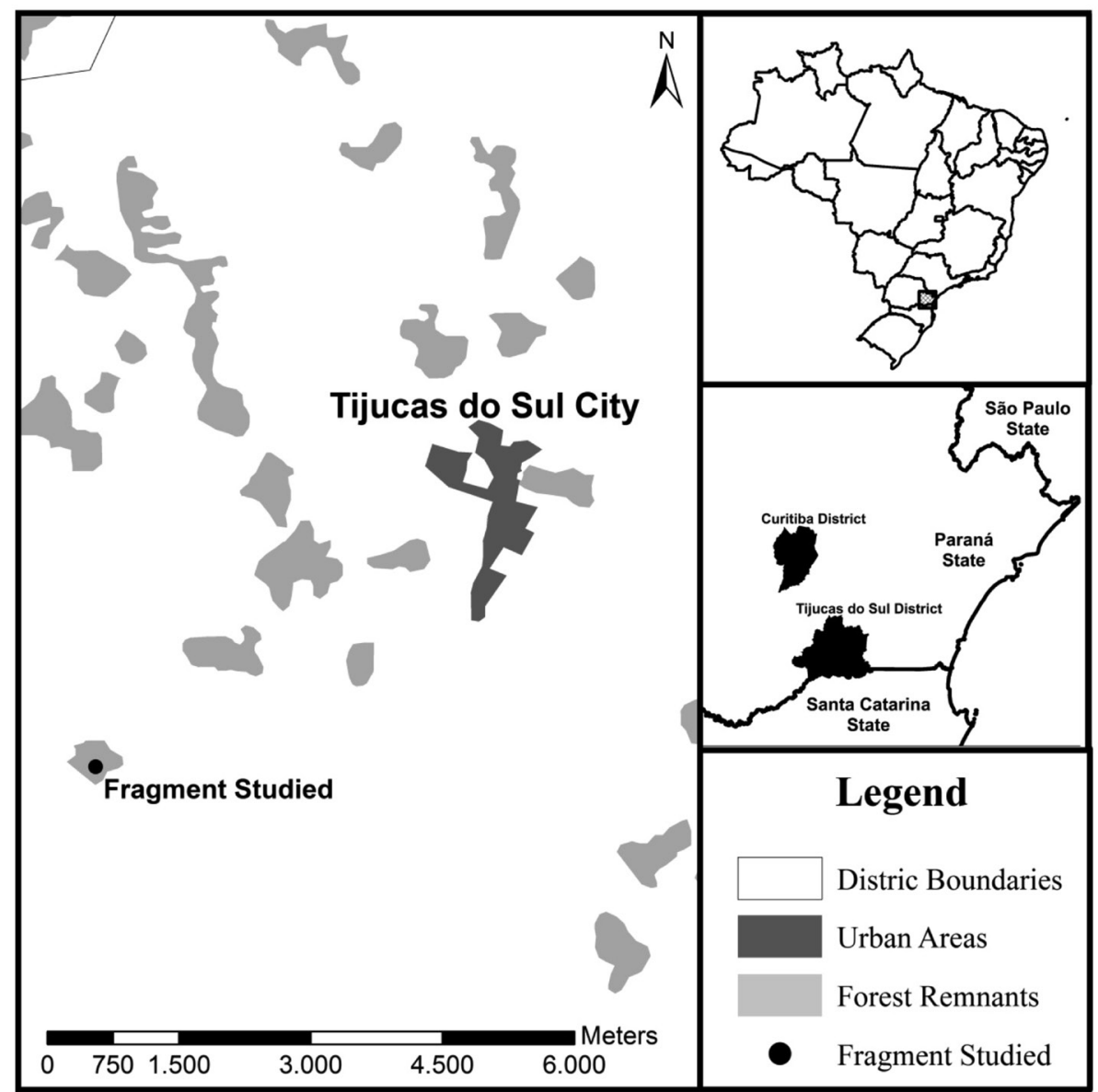

Fig. 1. Localization of the fragment studied (black point), in relation to Tijucas do Sul city, and District of Curitiba, state of Paraná, Brazil.

of $p<0.05$. Species diversity was compared among the years, and, for this purpose, a modified $t$-Test was used to compare diversities. The species were classified in four groups according to their preferential habitat: open area, bamboo specialist, edge and forest. To evaluate the relationship between the four groups and the species richness and the total abundance during the years, linear and nonlinear regressions were run. The numbers of adult and young individuals captured during the time period were log-transformed. The species list and nomenclature used here are according to the Brazilian Ornithological Records Committee (2011).

Landscape analysis. We classified land cover using Landsat Thematic Mapper data (30-m pixels, based primarily on bands 3, 4 and 5) for 1989, 1991, 1992, 1993, and 1994 (1990 data were generated by averaging the data from 1989 and 1991) available in the image archives of the Instituto Nacional de Pesquisas Espaciais - INPE/ATUS. The images were segmented and classified with the use of SPRING v. 7 (CAMARA et al., 1996). Land-cover classes were water, forest, tree plantation (Pinus elliottii and Eucalyptus sp.), open area (agriculture, pasture, bare soil, and abandoned field), and "capoeira" (native vegetation $\leq 2 \mathrm{~m}$ ). A circular area of 278 ha, where the study area is a central point, was selected.

Bird community and landscape changes. We selected four groups of birds according to preferential habitat use, including open-area (species that inhabit agriculture areas, pasture, and abandoned field), forest (species that inhabit areas with secondary or pioneer native forest including the forest floor, herb layer, shrub layer, understory, canopy, and emergents), bamboo (species that feed on bamboo seeds or insects associate with bamboo; Areta et al., 2009), and edge species (species that are not sensitive to forest border; RIES \& Sisk, 2010). Total abundance of all species belonging to different kinds of habitat was used to find correlations with landscape classes. Linear and non-linear regressions were used to analyze the change in abundance over time. Therefore, Pearson's correlation was used to determine the behavior of the groups and changes in land use for the years from 1989 to 1993 (data from 1994 was removed from the analysis) during the study period.

\section{RESULTS}

A total of 96 bird species were recorded in the study area (Appendix I) from 1,948 individuals captured during seven years with 20,160 hours/mist-nets of capture effort. The richness values were 114, 118 and 110 species as estimated by Chao 1, Jackknife 1 and Bootstrap, respectively (Fig. 2).

The bird community varied in species richness, 


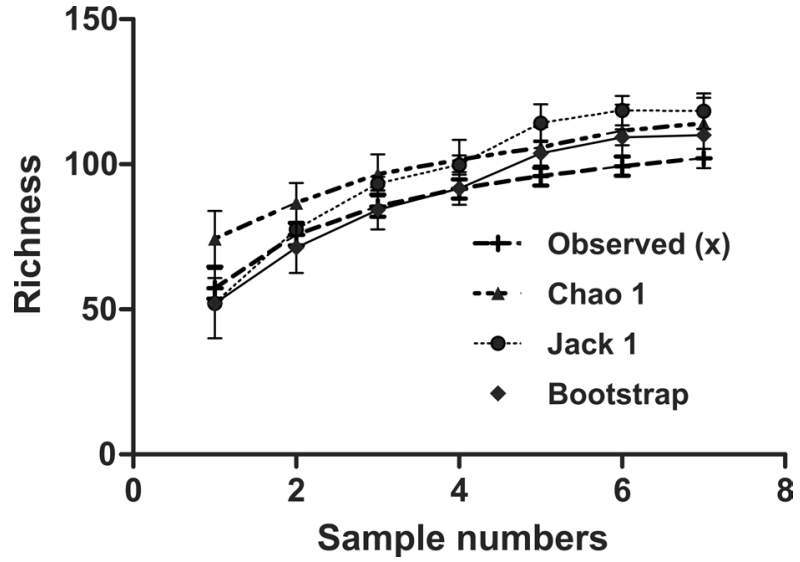

Fig. 2. Curve of species richness observed (Mao Tau) and estimated through Chao 1, Jackniffe 1 and Bootstrap considering a seven-year survey in an Araucaria forest fragment in state of Paraná, Southern Brazil.

abundance, and diversity (Tab. I) during the study period. Abundance was highest in 1993 and lowest in 1994. The diversity index was highest in 1991 and lowest in 1994. The low values for all indices in 1994 can be explained by the low sampling effort during that year. Species diversity differed among the years, and 1991, 1993 and 1994 were significantly different from the other years. The first three years of the study were quite homogeneous and, consequently, statistically similar (Tab. II).

Figure 3 shows the curve of species ranks according to the abundances recorded. Differences among species distribution curves according to abundance were significant $(F=3.29 ; p=0.003)$; a posttest indicated that only $1988(t=3.91 ; p<0.05)$ and 1989 $(t=3.13 ; p<0.05)$ differed significantly from 1993.

Fifteen families were recorded altogether, and the highest species richness was observed in 1991 ( $\mathrm{N}=61)$ and $1992(\mathrm{~N}=68)$. The family Tyrannidae was represented by the most species (mean $=15 \pm 5$ ) in all years, followed by Emberizidae (mean $=6.3 \pm 1)$ and Furnariidae (mean= $6 \pm 3.5$ ). Emberizidae and Tyrannidae had the highest number of individuals in 1992 and 1993, contributing substantially to the overall abundance in this period.

Species that showed the greatest change in abundance in 1992 and 1993 were Poospiza cabanisi, Haplospiza unicolor, Lathrotriccus euleri, Zonotrichia capensis, Lepidocolaptes falcinellus and Columbina talpacoti. Interestingly, the abundance of $P$. cabanisi and $H$. unicolor was associated with the flowering of large bamboo ("taquara"; Poaceae, Chusquea sp.) during this period. This reflects the abundance of species in the open-area and bamboo-specialist groups (Fig. $4 \mathrm{~A}$ and B; left column), which showed a logarithmic increase from 1992. The abundance of the edge and forest groups increased linearly (Fig. $4 \mathrm{C}$ and D; left column). The gain in species was greater for species of open areas and bamboo specialists (Fig. 4 A and B; right column). The gain in species was not significant for the edge and forest species (Fig. $4 \mathrm{C}$ and D; right column).

The abundance of adults captured did not differ during the study period. Therefore, the abundance of young individuals changed. The abundance of young individuals captured was lowest in 1990 and highest in 1993 (Fig. 5).

The results of the landscape analysis showed a dynamic change (Tab. III) over time in the classes of land use. The forest area increased mainly between 1992 and 1993 (Fig. 6). This change resulted from the cutting of trees (Pinus elliottii and Eucalyptus sp.), and a consequent decrease in forested areas and increase in open and "capoeira" areas. The forest, open-area, and bamboospecialist species were positively and significantly correlated with the changes in the forest and "capoeira" cover. The tree plantations were negatively correlated with all groups of birds, but not significantly (Tab. IV).

\section{DISCUSSION}

Considering the period of time assessed, the study area showed a high species richness for the capture method. This level of richness was unexpected for this fragment, which is isolated from other, larger areas of

Tab. I. Results for richness, abundance, Shannon, Simpson, evenness and equitability indices of bird community in an Araucaria forest fragment in state of Paraná, Southern Brazil, from 1988 through 1994.

\begin{tabular}{|c|c|c|c|c|c|c|c|}
\hline & 1988 & 1989 & 1990 & 1991 & 1992 & 1993 & 1994 \\
\hline Richness (S) & 52 & 50 & 50 & 59 & 68 & 66 & 29 \\
\hline Abundance $(\mathrm{N})$ & 160 & 174 & 171 & 182 & 377 & 778 & 103 \\
\hline Shannon (H') & 3.55 & 3.39 & 3.58 & 3.75 & 3.36 & 2.89 & 2.48 \\
\hline Simpson (D) & 0.96 & 0.94 & 0.96 & 0.97 & 0.92 & 0.89 & 0.81 \\
\hline Evenness $\left(\mathrm{e}^{\mathrm{H} / \mathrm{s}}\right)$ & 0.67 & 0.59 & 0.72 & 0.72 & 0.4 & 0.27 & 0.41 \\
\hline Equitability (J) & 0.90 & 0.86 & 0.91 & 0.92 & 0.80 & 0.69 & 0.73 \\
\hline
\end{tabular}

Tab. II. Comparison of bird diversity in an Araucaria forest fragment in state of Paraná, Southern Brazil among the different years of the study.

\begin{tabular}{|c|c|c|c|c|c|c|c|}
\hline & 1988 & 1989 & 1990 & 1991 & 1992 & 1993 & 1994 \\
\hline 1988 & & $t=1.27 ; p=0.20$ & $t=-0.46 ; p=0.64$ & $t=-1.97 ; p=0.05$ & $t=-1.21 ; p=0.22$ & $t=5.84 ; p=0.00$ & $t=6.42 ; p=0.00$ \\
\hline 1989 & & & $t=-1.80 ; p=0.07$ & $t=3.23 ; p=0.00$ & $t=-1.6 ; p=0.87$ & $t=-4.04 ; p=0.00$ & $t=-5.43 ; p=0.00$ \\
\hline 1990 & & & & $t=-1.66 ; p=0.00$ & $t=-1.80 ; p=0.07$ & $t=7.09 ; p=0.00$ & $t=-6,93 ; p=0.00$ \\
\hline 1991 & & & & & $t=3.37 ; p=0.00$ & $t=-8.83 ; p=0.00$ & $t=7.87 ; p=0.00$ \\
\hline 1992 & & & & & & $t=4.71 ; p=0.00$ & $t=5.73 ; p=0.00$ \\
\hline 1993 & & & & & & & $t=3.30 ; p=0.00$ \\
\hline
\end{tabular}



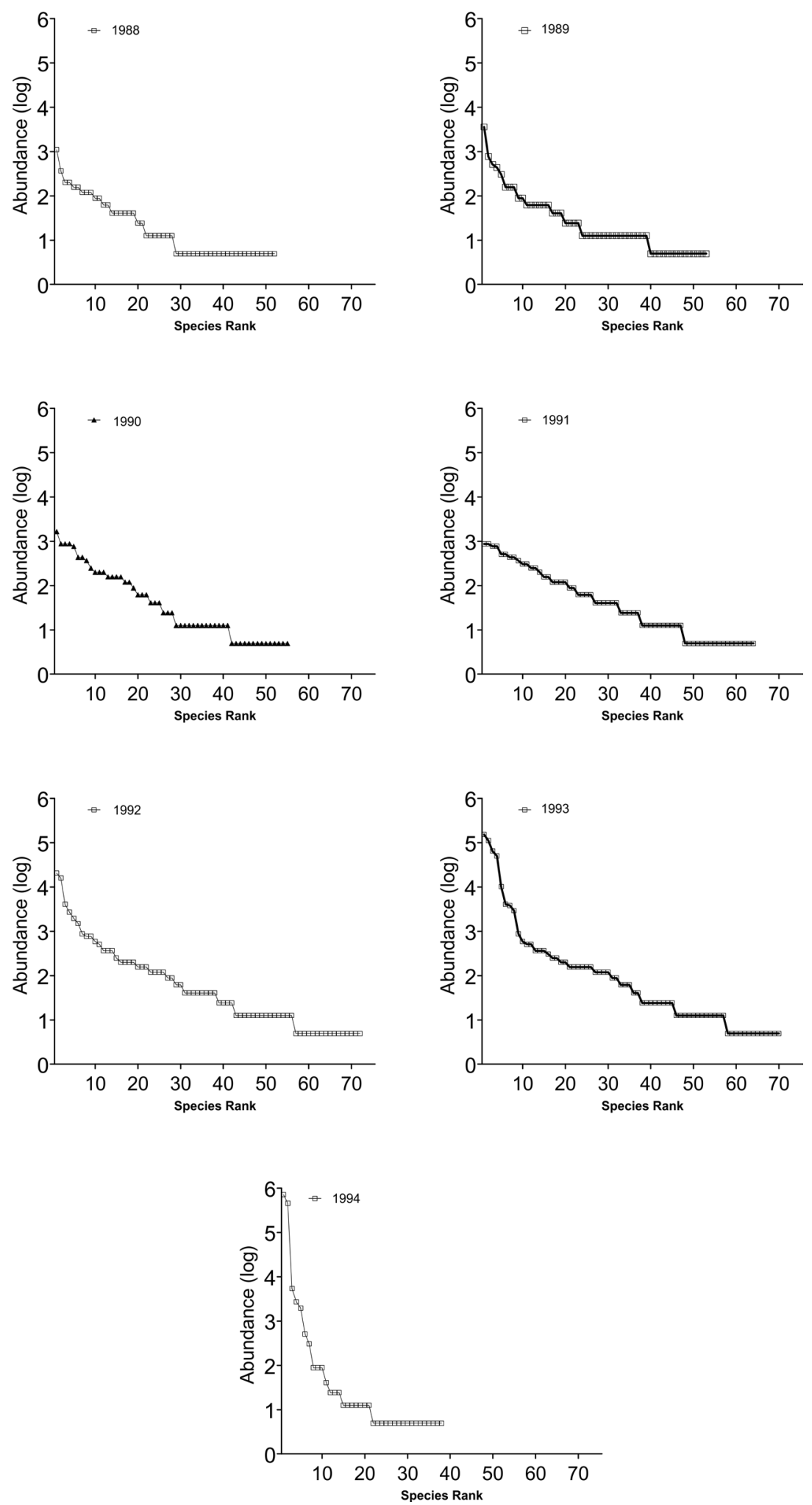

Fig. 3. Bird species distribution by abundance in each of the years studied, from 1988 to 1994 in an Araucaria forest fragment in state of Paraná, Southern Brazil.

native forest. The estimated number of species was not much higher than the actual number collected; the most optimistic estimator was Jackknife 1, with 16 species over the estimated number. In another fragment studied recently, 10 ha in area and located next to the area of the present study, 48 species were recorded in a threeyear period (Bispo \& Scherer-Neto, 2010). On the other hand, KAMINSKI \& CARRANO (2006) in an area 20 times greater and with similar vegetation registered 217 species, which means two times more species. 

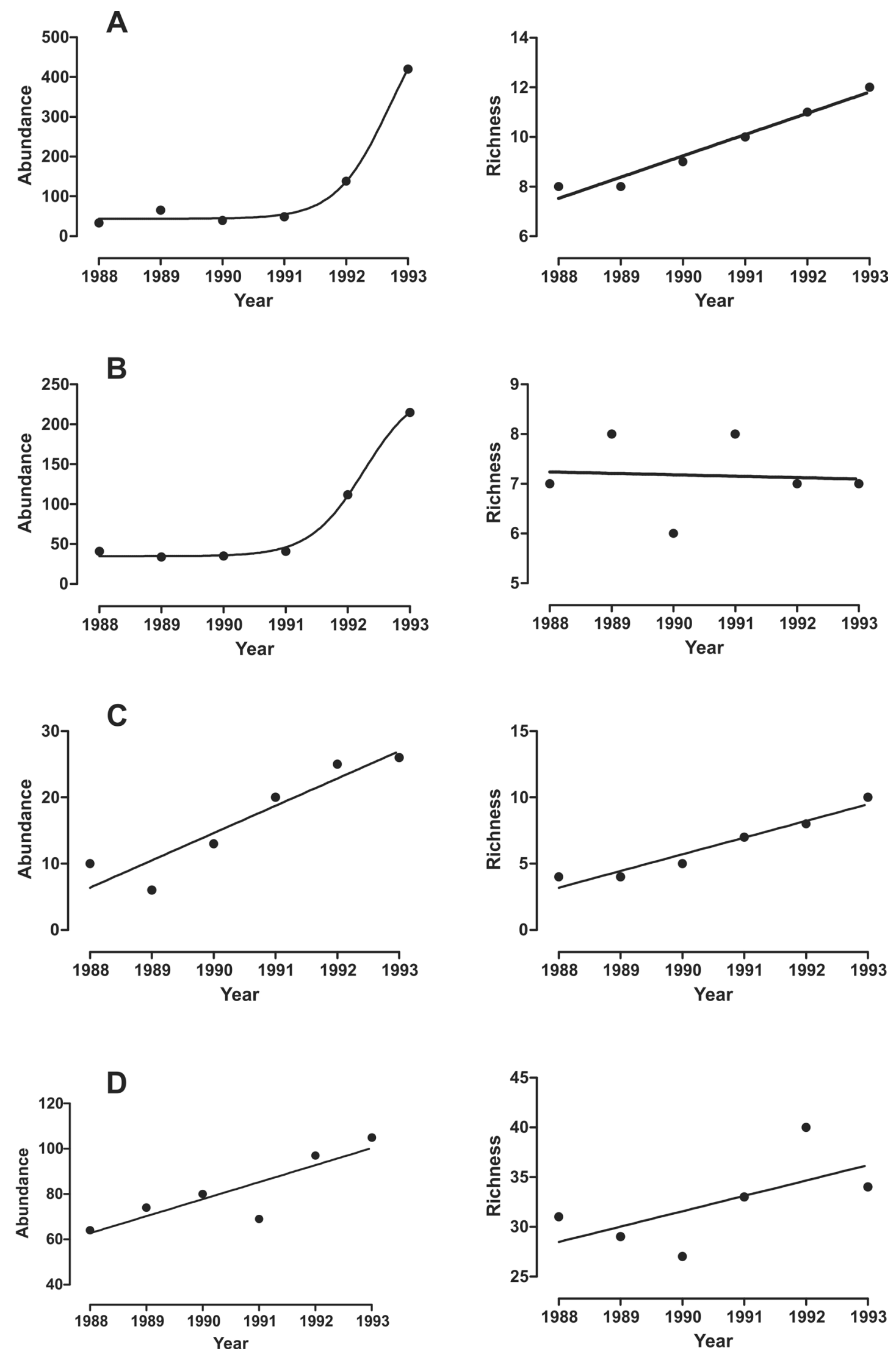

Fig. 4. Distribution abundance (left column) and richness (right column) of the species of open areas (A), bamboo specialists (B), edge (C), and forest (D) along of the year intervals assessed. 


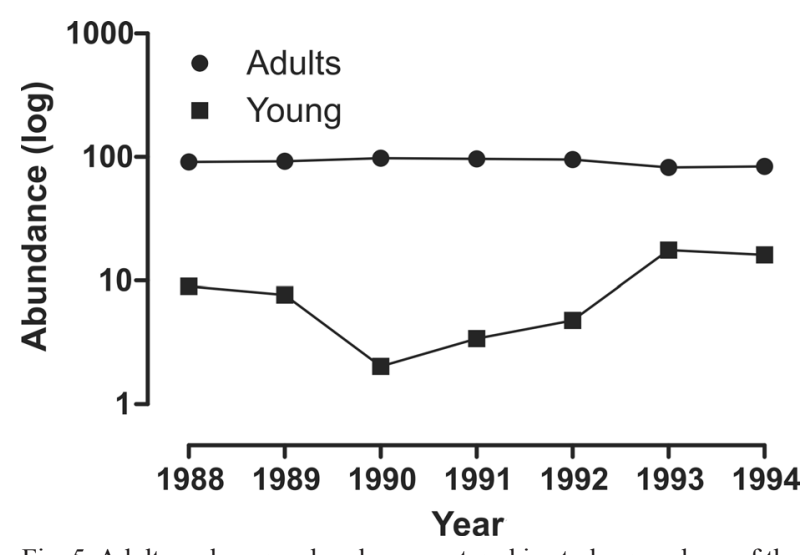

Fig. 5. Adults and young abundance captured in study area along of the studied time interval in Tijucas do Sul, state of Paraná, Southern Brazil.

However, the richness values for each of the years were lower than the richness obtained for the entire period, with a total mean diversity of 40.5 species, i.e., less than half of the total 96 species observed in the seven-year period. The relatively high number of species found in the study area is a result of the large flux of individuals that were captured in one or two years, although in low abundance $(n=32)$. Many of these species either belong to open environments or use the forest as a refuge for feeding and reproduction. Some of them are locally rare and endemic to the Atlantic Rain Forest, and were carrying out dispersal movements, such as, for example, Piculus aurulentus, Xiphocolaptes albicollis, Pachyramphus viridis and Muscipipra vetula.

Anjos \& Boçon (1999) studied 11 small fragments (0.4-40 ha) located in the central upland of the state of Paraná, and over a five-month period recorded about 60 species in two fragments, each of 10 ha. In another fragment with an area of 840 ha, ANJos \& Boçon (1999) observed 102 species, a number similar to that observed in our seven-year study. Therefore, changes in richness over the years may be associated with different functions performed by the mosaic of environments. In other words, the mosaic may function as a stepping-stone for many visiting species, a shelter for reproduction, a refuge from predators, and a source of food for other species.

Long-term studies in fragmented areas may provide information on the stability of communities and the species turnover rate. A project that assessed the effects of fragmentation in the Amazon region is among the few that have provided important long-term information. In this study by Stouffer et al. (2011), an analysis carried out before isolation and 25 years after isolation showed that the colonization and extinction rates defined the dynamics of the bird community in the fragments. Also, the results showed that the extinction rate in 100-ha fragments was between 10 and $15 \%$. Interestingly, the species richness apparently remained the same before and after a long period of isolation. The authors explained this result in light of

Tab. III. Size of the area (ha) occupied according to land-use class, in each year of the study.

\begin{tabular}{lllllll}
\hline Classes of land use & \multicolumn{1}{c}{1989} & \multicolumn{1}{c}{1990} & \multicolumn{1}{c}{1991} & \multicolumn{1}{c}{1993} & 1994 \\
\hline Water & 1.02 & 1.90 & 7.85 & 2.12 & 0.92 & 1.02 \\
Forest & 31.60 & 31.15 & 30.70 & 32.00 & 41.80 & 31.60 \\
Forestry & 55.80 & 57.25 & 58.70 & 60.50 & 66.70 & 55.80 \\
Recovering (Capoeira) & 3.80 & 3.1 & 2.40 & 1.90 & 36.40 & 3.80 \\
Open area & 179.70 & 169.9 & 160.10 & 164.60 & 190.40 & 179.70 \\
\hline
\end{tabular}

Tab. IV. Correlations between size of area per year and total abundance of habitat-specialist species (*, significant to $\mathrm{p}<0.05$; ns, not significant).

\begin{tabular}{lcccc}
\hline \multirow{2}{*}{ Habitat of bird species } & \multicolumn{4}{c}{ Environment } \\
\cline { 2 - 5 } & Forest & Tree plantation & Recovering & Open area \\
\hline Open area & $0.98^{*}$ & $-0.78^{\text {ns }}$ & $0.83^{*}$ & $0.34^{\text {ns }}$ \\
Edge & $0.69^{\text {ns }}$ & $-0.28^{\text {ns }}$ & $0.74^{\text {ns }}$ & $0.34^{\text {ns }}$ \\
Bamboo & $0.97^{*}$ & $-0.69^{\text {ns }}$ & $0.90^{*}$ & $0.49^{\text {ns }}$ \\
Forest & $0.84^{*}$ & $-0.48^{\text {ns }}$ & $0.89^{*}$ & $0.38^{\text {ns }}$ \\
\hline
\end{tabular}

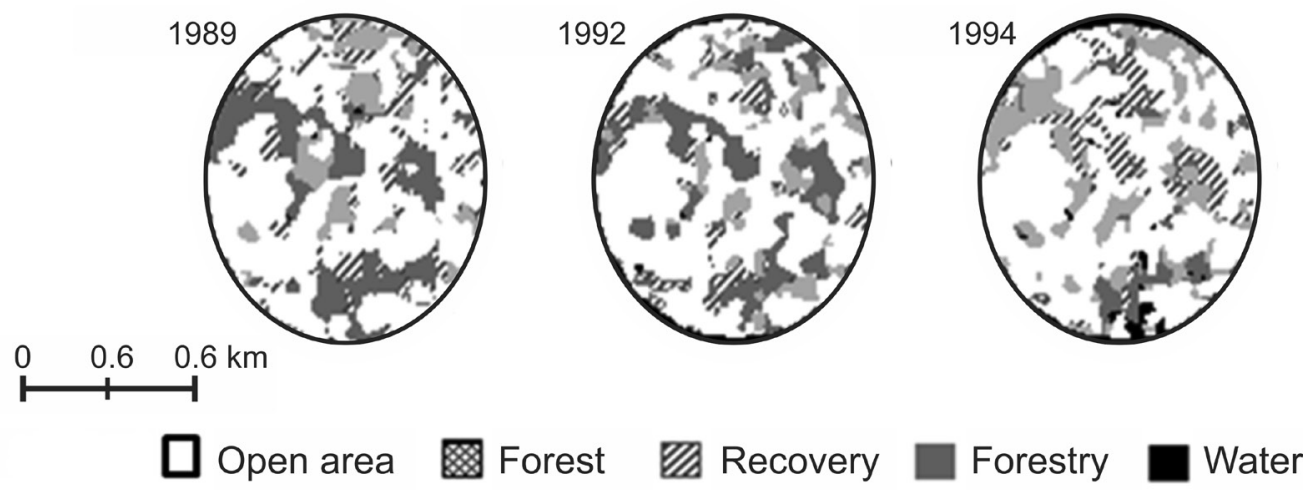

Fig. 6. Evolution of the landscape along 1991 to 1994 from analysis of Landsat TM images of Tijucas do Sul, state of Paraná, Southern Brazil. 
the high colonization rate observed in these isolated fragments. The results of the present study coincide with the results obtained in the fragments of the Amazon region, as evidenced by the low variation of species richness over the period of time assessed. However, many species were recorded only once and in different years and/or seasons, resulting in a high species turnover rate.

Abundance and richness values were similar from 1988 to 1993; however, the fewest individuals were recorded in 1994, which may be an effect of a lower sampling effort during that year. Results obtained for the Shannon-Wiener and Simpson indexes showed peak diversity in 1991, coincidentally halfway through the sampling period. This result can be explained by the cutting of the eucalyptus trees, which improved conditions for the understory plants; and when the crop fields were abandoned, new "capoeiras" were developed, which were attractive for many bird species, including Elaenia sp., Volatinia jacarina, Zonotrichia capensis and Columbina talpacoti. This contrasts with the data for 1992 and 1993, which showed an increase in the abundance of some species that was directly related to the flowering of "taquara", such as Poospiza cabanisi, Haplospiza unicolor and Pyrrhocoma ruficeps. Specifically for the Furnariidae, in 1992, 10 species were recorded in this study area, an impressive richness level compared to the study by FÁvARO et al. (2006), who recorded 14 species in an area of about $24,000 \mathrm{~km}^{2}$ in the same kind of habitat. In both studies, the understory species were most abundant, including Synallaxis ruficapilla, S. cinerascens and Syndactyla rufosuperciliata. Generally, species of Synallaxis are associated with the presence of "taquara" in many other secondary habitats (Willis \& Schuchmann, 1993; Remsen, 2003; FÁvARo et al., 2006).

Additionally, in 1993 the families Emberizidae and Tyrannidae showed the greatest increase in abundant species in the mosaic, which confirms the nomadic behavior of some species that continuously move between environments in search of resources. The most diverse families included some omnivorous, granivorous and insectivorous species that can live in edges, such as Elaenia spp., Camptostoma obsoletum, Vireo olivaceus and Synallaxis ruficapilla.

PARKer et al. (1997) studied several extensive bamboo stands in Northern Brazil, where they found about 10 species of bamboo specialists. The bamboo species of the Poaceae family had primarily inhabited the Atlantic Forest, where most of the species occur in gaps and disturbed areas (JuDzIEwicz et al., 1999). Therefore, the rise in disturbed fragments that are colonized by bamboo increases the probability of occurrence of bamboo specialists. SANTANA \& AnJos (2010) studied the effect of bamboo species (Chusquea sp.) and observed that richness and abundance increased significantly in areas dominated by bamboo and the most common species were Drymophila rubricollis, Conopophaga lineata, Hylopezus nattereri, Synallaxis cinerascens, and Hemitriccus diops. Many other investigators have recorded associations between these species and the presence of bamboo in the forest (Leme, 2001; Fitzpatrick, 2004; Volpato et al., 2006; Areta et al., 2009). Bamboo specialists were estimated to comprise $5 \%$ of the bird community in the Paraná region (ANJos et al., 2007).

In conclusion, this study contributed to understanding the dynamics of small, isolated forest fragments and their surroundings in the domains of the Atlantic Rain Forest. The results showed that small fragments can serve as a shelter for reproduction, a refuge, a source of food, and help in the connection between fragments. Our results also show the importance of conservation of these areas and their contribution to maintaining diversity among populations of many species and avoiding local extinction because they could survive in a fragmented landscape.

Acknowledgments. We would like to thank many persons who participated in the field work of the Paraná Bird Watchers Club at the beginning of the survey, and in later years the personnel of the "Capão da Imbuia" Natural History Museum, Curitiba, especially Adão Schroeder (in memoriam), Joaquim Carvalho Ribeiro (in memoriam), Luiz Carlos Sieben, Luiz F. F. de Macedo, Sebastião C. Pereira, Valdenisio Ferreira dos Santos, Pedro Sanches, Valdi Paula Gonçalves, Eduardo Carrano and Douglas Kajiwara, among many other friends. This study would not have been possible without the permission of the owner of the land and the company PANAGRO Reflorestadora, Mr. Sergius Erdelyi. Our best thanks to Louri Klemann Jr. for providing the maps of the study area.

\section{REFERENCES}

Anjos, L. 2001. Bird communities in five Atlantic forest fragments in southern Brazil. Ornitología Neotropical 12:11-27.

2007. A eficiência do método de amostragem por pontos de escuta na avaliação da riqueza de aves. Revista Brasileira de Ornitologia 15(2):239-243.

Anjos, L. \& Boçon, R. 1999. Bird communities in natural forest patches in southern Brazil. Wilson Bulletin 111:397-414.

Anjos, L.; Volpato, G. H.; Lopes, E. V.; Serafini, P. P.; Poletto, F. \& Aleixo, A. 2007. The importance of riparian forest for the maintenance of bird species richness in an Atlantic Forest remnant, southern Brazil. Revista Brasileira de Zoologia 24(4):1078-1086.

Areta, J. I.; Bodrati, A. \& Cockle, K. 2009. Specialization on Guadua bamboo seeds by three bird species in the Atlantic Forest of Argentina. Biotropica 41(1):66-73.

BierregaArd JR., R. O. \& Lovejoy. T. E. 1989. Effects of forest fragmentation on Amazonian understory bird communities. Acta Amazonica 19:215-241.

Bierregaard Jr., R. O.; Lovejoy, T. E.; Kapos, V.; dos Santos, 
A. A. \& Hutchings, R. W. 1992. The biological dynamics of tropical rainforest fragments. BioScience 42:859-866.

Bierregaard JR., R. O. \& Stouffer, P. C. 1997. Understory birds and dynamic habitat mosaics in Amazonian rainforests. In: Laurance, W. F. \& Bierregaard JR., R. O. eds. Tropical Forest Remnants: The Ecology, Conservation, and Management of Fragmented Communities. Chicago, University of Chicago Press. p. 138-155.

Bispo, A. A. \& Scherer-Neto, P. 2010. Taxocenose de aves em um remanescente da Floresta com Araucária no Sudeste do Paraná, Brasil. Biota Neotropica 10(1):121-130.

Brooks, T.; Tobias, J. \& Balmford, A.1999. Deforestation and bird extinctions in the Atlantic forest. Animal Conservation 2:211-222.

Camara, G.; Souza, R. C. M.; Freitas, U. M. \& Garrido, J. 1996. SPRING, integrating remote sensing and GIS with object oriented data modelling. Computers \& Graphics 15(6):1322.

Colwell, R. K. 2009. EstimateS: Statistical estimation of species richness and shared species from samples. Version 8.2. User's Guide and application. Available at $<$ http://purl. oclc.org/estimates>. Accessed on: 20.11.2011.

CBRO - Comitê Brasileiro de Registros Ornitológicos (online). 2011. Listas das aves do Brasil. 10ed. Versão 25/01/2011. Available at <http://www.cbro.org.br>. Accessed on 22.03.2011.

Donatelli, R. J.; Ferreira, C. D.; Dalbeto, A. C. \& Posso, S. R. 2007. Análise comparativa da assembléia de aves em dois remanescentes florestais no interior de São Paulo, Brasil. Revista Brasileira de Zoologia 24(2):362-375.

Fávaro, F. L.; Anjos, L.; Lopes, E. V.; Mendonça, L. B. \& Volpato, G. H. 2006. Efeito do gradiente altitudinal/latitudinal sobre espécies de aves florestais da família Furnariidae na Bacia do Rio Tibagi, Paraná, PR. Revista Brasileira de Zoologia 23(1):261-266.

Ferreira, J. C. V. 1999. O Paraná e Seus Municípios. 2ed. Maringá, Memória Brasileira. 520p.

Fitzpatrick, J. W. 2004. Family Tyrannidae (Tyrant-flycatchers). In: Del Hoyo, J.; Elliot, A. \& Christie, D. A. eds. Handbook of the Birds of the World. v. 9. Cotingas to Pipits and Wagtails. Barcelona, Lynx. p. 170-225.

HaAs, C. G. 1995. Dispersal and use of corridors by birds in wooded patches on an agricultural landscape. Conservation Biology 9:845-854.

IAPAR. 1978. Cartas climáticas básicas do Estado do Paraná. Londrina: Fundação Instituto Agronômico do Paraná. 38 p.

Johnson, M. L. \& Gaines, M. S. 1990. Evolution of dispersal: theoretical models and empirical tests using birds and mammals. Annual Review of Ecology and Systematics 21:449-480.

Judziewicz, E. J.; Clark, L. G.; Londono, X. \& Stern, M. J. 1999. American Bamboos. Washington D.C., Smithsonian Institution Press. 392p.

Kaminski, N. \& Carrano, E. 2006. Avifauna da Serra do Cabral e áreas adjacentes. Estudos de Biologia 28(64):119-128.

Laurance, S. G. W.; Stouffer, P. C. \& Laurance, W. F. 2004. Effects of road clearings on movement patterns on the understory rainforest birds in Central Amazonia. Conservation Biology 18:1099-1109.

Laurance, W. F.; Lovejoy, T. E.; Vasconcelos, H. L.; Bruna, E. M.; Didham, R. K.; Stouffer, P. C.; Gascon, C.; Bierregaard Jr., R.O; Laurance, S. G. \& Sampaio, E. 2002. Ecosystem decay of Amazonian forest fragments: A 20 year investigation. Conservation Biology 16:605-618.

Laurance, W. F. \& Vasconcelos, H. L. 2009. Conseqüências ecológicas da fragmentação florestal na Amazônia. Oecologia Brasiliensis 13:434-451.

Leme, A. 2001. Foraging patterns and resource use in four sympatric species of antwrens. Journal of Field Ornithology 72(2):221-227.

Liebsch, D. \& Acra, L. A. 2004. Riqueza de espécies de subbosque de um fragmento de floresta ombrófila mista em Tijucas do Sul, PR. Ciência Florestal 4:67-76.

Loво, D. H. 2003. Araucária: necessidade de conservação e recomposição. Florestar Estatístico 14(6):10-11.

Maldonado-Coelho, M. \& Marini, M. A. 2004. Mixed-species bird flocks from Brazilian Atlantic Forest: the effects of forest fragmentation on their size, richness, and stability. Biological Conservation 116(1):19-26.

Marini, M. A. 2001. Effects of forest fragmentation on birds of the cerrado region, Brazil. Bird Conservation International 11:11-23.

Metzger, J. P.; Martensen, A. C.; Dixo, M.; Bernacci, L. C.; Ribeiro, M. C.; Teixeira, A. M. G. \& Pardini, R. 2009. Time-lag in biological responses to landscape changes in a highly dynamic Atlantic forest region. Biological Conservation 142:1166-1177.

Moore, R. P.; Robinson, W. D.; Lovette, I. J. \& Robinson, T. R. 2008. Experimental evidence for extreme dispersal limitation in tropical forest birds. Ecology Letters 11:960-968.

Opdam, P. 1991. Metapopulation theory and habitat fragmentation: a review of holarctic breeding bird studies. Landscape Ecology 5:93-106.

Parker III, T. A.; Stotz, D. F. \& Fitzpatrick, J. W. 1997. Notes on Avian Bamboo Specialists in Southwestern Amazonian Brazil. Ornithological Monographs 48:543-547.

Pozza, D. D. \& Pires, J. S. R. 2003. Bird communities in two fragments of semideciduous forest in rural São Paulo state. Brazilian Journal of Biology 63(2):307-319.

Remsen, J.V. 2003. Family Furnariidae (Ovenbirds),. In: Del Hoyo, J.; Elliott, A. \& Christie, D. A. eds. Handbook of the Birds of the World. v. 8. Barcelona, Lynx Editions. p. 162-357.

Ribeiro, M. C.; Metzger, J. P.; Martensen, A. C.; Ponzoni, F. J. \& Hirota, M. M. 2009. The Brazilian Atlantic forest: How much is left, and how is the remaining forest disturbed? Implications for conservation. Biological Conservation 142:1141-1153.

Ribon, R.; Simon, J. E. \& Mattos, G. T. 2003. Bird extinctions in Atlantic Forest fragments of the Viçosa region, southeastern Brazil. Conservation Biology 17:1827-1839.

RIES, L. \& SISK, T. D. 2010. What is an edge species? The implications of sensitivity to habitat edges. Oikos 119(10): $1636-1642$.

SAntanA, C. R. \& Anjos, L. 2010. Associação de aves a grupamentos de bambu na porção Sul da Mata Atlântica, Londrina, Estado do Paraná, Brasil. Biota Neotropica 10(2):39-44.

Stouffer, P. C.; Johnson, M. L.; Bierregaard JR., R. O. \& Lovejoy, T. E. 2011. Understory bird communities in Amazonian rainforest fragments: species turnover through 25 years postisolation in recovering landscape. PLoS ONE 6(6): 20543.

Stratford, J. A. \& Stouffer, P. 1999. Local extinctions of terrestrial insectivorous birds in a fragmented landscape near Manaus, Brazil. Conservation Biology 13(6):1416-1423.

Turner, I. M. 1996. Species loss in fragments of tropical rainforest: a review of the evidence. Journal of Applied Ecology 33:200-209.

Veloso, H. P.; Rangel-Filho, A. L. R. \& Lima, J. C. A. 1991. Classificação da vegetação brasileira adaptada a um sistema universal. Rio de Janeiro, IBGE. 123p.

Volpato, G. H.; Anjos, L.; Poletto, F.; Serafini, P. P.; Lopes, E. V. \& FÁvaro, F. L. 2006. Terrestrial passerines in an Atlantic forest remnant of Southern Brazil. Brazilian Journal Biology 66(2a):473-478.

Wiens, J. A. 1994. The Ecology of Bird Communities. Cambridge, Cambridge University Press. 539p.

Willis, E. O. \& Schuchmann, K. L. 1993. Comparison of cloudforest avifaunas in Southeastern Brazil and western Colombia. Ornitología Neotropical 4:55-63. 
Appendix I. List of families and species of birds captured in the Araucaria Forest fragment in the County of Tijucas do Sul, state of Paraná, from 1988 through 1994, according CBRO (2011). Species were classified according to preferential habitat used (hu), as: OA, open-area species; Fr, forest species; Ed, edge species; Bb, bamboo specialists.

\begin{tabular}{|c|c|c|c|c|c|c|c|c|c|}
\hline FAMILY & Species & $\mathrm{hu}$ & 1988 & 1989 & 1990 & 1991 & 1992 & 1993 & 1994 \\
\hline FALCONIDAE & Micrastur ruficollis (Vieillot, 1817) & Fr & & & 1 & & & & \\
\hline \multirow[t]{3}{*}{ COLUMBIDAE } & Columbina talpacoti (Temminck, 1811) & $\mathrm{OA}$ & 2 & 8 & 9 & 8 & 16 & 12 & 3 \\
\hline & Leptotila verreauxi (Bonaparte, 1855) & $\mathrm{Fr}$ & & & & & 1 & & \\
\hline & Leptotila rufaxilla (Richard \& Bernard, 1792) & Fr & 1 & 2 & 2 & & 1 & 2 & \\
\hline ALCEDINIDAE & Chloroceryle americana (Gmelin, 1788) & Fr & & & & & 2 & 1 & \\
\hline \multirow[t]{4}{*}{ PICIDAE } & Picumnus temminckii (Lafresnaye, 1845) & Ed & & & 3 & & & 2 & \\
\hline & Picumnus nebulosus Sundevall, 1866 & Ed & & & 1 & 3 & 5 & 1 & \\
\hline & Veniliornis spilogaster (Wagler, 1827) & Fr & & & 1 & 1 & 2 & 3 & \\
\hline & Piculus aurulentus (Temminck, 1821) & $\mathrm{Fr}$ & & & 1 & 1 & 1 & & \\
\hline \multirow[t]{6}{*}{ THAMNOPHILIDAE } & Dysithamnus mentalis (Temminck, 1823) & $\mathrm{Fr}$ & & & & & 2 & & \\
\hline & Thamnophilus ruficapillus (Vieillot, 1816) & $\mathrm{OA}$ & & & & 3 & 1 & 2 & \\
\hline & Thamnophilus caerulescens (Vieillot, 1816) & Fr & 2 & 2 & 6 & 10 & 5 & 5 & \\
\hline & Batara cinerea (Vieillot, 1819) & Fr & 1 & 1 & 2 & 2 & 1 & 1 & \\
\hline & Mackenziaena leachii (Such, 1825) & Fr & 1 & 1 & 1 & & 1 & & \\
\hline & Drymophila malura (Temminck, 1825) & Ed & 1 & 1 & & 3 & 1 & 4 & \\
\hline CONOPOPHAGIDAE & Conopophaga lineata (Wied, 1831) & Fr & 6 & 7 & 8 & 3 & 6 & 6 & \\
\hline SCLERURIDAE & Sclerurus scansor (Ménétriès, 1835) & $\mathrm{Fr}$ & & & 1 & & 2 & & \\
\hline \multirow[t]{5}{*}{ DENDROCOLAPTIDAE } & Sittasomus griseicapillus (Vieillot, 1818) & Fr & 1 & 1 & 2 & 2 & 1 & 6 & \\
\hline & Xiphorhynchus fuscus (Vieillot, 1818) & Fr & 1 & & & & & & 1 \\
\hline & Lepidocolaptes falcinellus (Cabanis \& Heine, 1859) & Fr & 1 & 1 & 2 & 3 & 2 & 5 & 1 \\
\hline & Dendrocolaptes platyrostris (Spix, 1825) & Fr & 3 & 3 & 6 & 5 & 4 & 3 & \\
\hline & Xiphocolaptes albicollis (Vieillot, 1818) & $\mathrm{Fr}$ & & & & & & 2 & \\
\hline \multirow[t]{11}{*}{ FURNARIIDAE } & Xenops rutilans $($ Temminck, 1821$)$ & Fr & & & & & & 1 & \\
\hline & Philydor rufum (Vieillot, 1818) & Fr & & 2 & & 1 & 2 & 2 & \\
\hline & Heliobletus contaminatus (Berlepsch, 1885) & Fr & 1 & & 1 & 1 & 1 & 2 & \\
\hline & Syndactyla rufosuperciliata (Lafresnaye, 1832) & Fr & 2 & 3 & & 5 & 3 & 2 & \\
\hline & Cichlocolaptes leucophrus (Jardine \& Selby 1830) & $\mathrm{Fr}$ & & & 4 & 1 & & & \\
\hline & Clibanornis dendrocolaptoides (Pelzeln, 1859) & $\mathrm{Bb}$ & & & & 2 & & & \\
\hline & Synallaxis ruficapilla (Vieillot, 1819) & Ed & 4 & 1 & 4 & 2 & 4 & 2 & \\
\hline & Synallaxis cinerascens (Temminck, 1823) & Ed & & 3 & 1 & 4 & 2 & 3 & \\
\hline & Synallaxis spixi (Sclater, 1856) & Ed & & 1 & 1 & 3 & 2 & 2 & \\
\hline & Cranioleuca obsoleta (Reichenbach, 1853) & Fr & & 2 & 2 & 1 & 1 & & \\
\hline & Cranioleuca pallida (Wied, 1831) & Fr & & & 1 & & 3 & & \\
\hline PIPRIDAE & Chiroxiphia caudata (Shaw \& Nodder, 1793) & Fr & 1 & & 2 & 2 & 1 & 5 & 2 \\
\hline \multirow[t]{5}{*}{ TITYRIDAE } & Schiffornis virescens (Lafresnaye, 1838) & Fr & & & & 1 & & 2 & \\
\hline & Pachyramphus viridis (Vieillot, 1816) & $\mathrm{Fr}$ & & 1 & & 2 & 1 & & \\
\hline & Pachyramphus castaneus (Jardine \& Selby, 1827) & Fr & 1 & & 1 & 1 & 1 & & \\
\hline & Pachyramphus polychopterus (Vieillot, 1818) & Fr & 2 & 1 & 1 & 1 & & & 1 \\
\hline & Pachyramphus validus (Lichtenstein, 1823) & Fr & 2 & 2 & & & & 1 & \\
\hline INSERTAE SEDIS & Platyrinchus mystaceus (Vieillot, 1818) & Fr & 4 & 3 & 4 & 2 & 5 & 9 & \\
\hline \multirow[t]{6}{*}{ RYNCHOCYCLIDAE } & Mionectes rufiventris (Cabanis, 1846) & Fr & & & & 1 & & & 1 \\
\hline & Phylloscartes eximius (Temminck, 1822) & Fr & & 3 & & & 1 & & \\
\hline & Phylloscartes ventralis (Temminck, 1824) & Fr & 3 & 1 & 6 & 3 & 3 & 2 & 1 \\
\hline & Tolmomyias sulphurescens (Spix, 1825) & Fr & 1 & & & & 2 & 2 & \\
\hline & Poecilotriccus plumbeiceps (Lafresnaye, 1846) & $\mathrm{OA}$ & 1 & 1 & & 1 & & 6 & \\
\hline & Hemitriccus obsoletus (Miranda-Ribeiro, 1906) & $\mathrm{Fr}$ & 1 & & & & & & \\
\hline \multirow[t]{10}{*}{ TYRANNIDAE } & Camptostoma obsoletum (Temminck, 1824) & $\mathrm{OA}$ & 1 & 1 & 1 & 1 & 3 & 1 & 1 \\
\hline & Elaenia flavogaster (Thunberg, 1822) & Ed & 1 & & & & & 1 & \\
\hline & Elaenia parvirostris (Pelzeln, 1868) & $\mathrm{OA}$ & 3 & 1 & & & & & \\
\hline & Elaenia mesoleuca (Deppe, 1830) & $\mathrm{OA}$ & & & & & 8 & 36 & 41 \\
\hline & Elaenia obscura (d’Orbigny \& Lafresnaye, 1837) & Ed & 4 & & & & & 6 & \\
\hline & Elaenia sp. & Ed & 6 & & & & & & \\
\hline & Myiopagis viridicata (Vieillot, 1817) & Fr & & & & & 1 & & \\
\hline & Serpophaga subcristata (Vieillot, 1817) & $\mathrm{OA}$ & 2 & & & 2 & 5 & 3 & \\
\hline & Myiarchus tuberculifer (d'Orbigny \& Lafresnaye, 1837) & Ed & & & & 7 & & & \\
\hline & Myiarchus swainsoni (Cabanis \& Heine, 1859) & Ed & & & 1 & 2 & 1 & & \\
\hline
\end{tabular}


Appendix I. Continuation...

\begin{tabular}{|c|c|c|c|c|c|c|c|c|c|}
\hline FAMILY & Species & $\mathrm{hu}$ & 1988 & 1989 & 1990 & 1991 & 1992 & 1993 & 1994 \\
\hline & Myiarchus ferox (Gmelin, 1789) & Ed & & & 3 & 4 & 2 & 1 & 1 \\
\hline & Myiarchus tyrannulus (Statius Müller, 1776) & $\mathrm{Ed}$ & & & & & & 3 & \\
\hline & Pitangus sulphuratus (Linnaeus, 1766) & $\mathrm{OA}$ & 1 & 1 & & 2 & & & \\
\hline & Myiodynastes maculatus (Statius Müller, 1776) & $\mathrm{Fr}$ & 2 & & 2 & 2 & 1 & & \\
\hline & Myiophobus fasciatus (Statius Müller, 1776) & $\mathrm{OA}$ & 3 & 1 & 1 & 2 & 1 & 2 & 2 \\
\hline & Cnemotriccus fuscatus (Wied, 1831) & $\mathrm{Fr}$ & & & & 2 & & & \\
\hline & Lathrotriccus euleri (Cabanis, 1868) & $\mathrm{Fr}$ & 4 & 4 & & 1 & 3 & 11 & 1 \\
\hline & Contopus cinereus (Spix, 1825) & $\mathrm{Fr}$ & 1 & & & 1 & 1 & & \\
\hline & Knipolegus cyanirostris (Vieillot, 1818) & $\mathrm{Fr}$ & 1 & 2 & 1 & & 1 & 1 & \\
\hline & Muscipipra vetula (Lichtenstein, 1823) & $\mathrm{Fr}$ & & & & & 1 & & \\
\hline \multirow[t]{3}{*}{ VIREONIDAE } & Cyclarhis gujanensis (Gmelin, 1789) & $\mathrm{Fr}$ & 6 & 3 & 6 & 6 & 8 & 6 & 1 \\
\hline & Vireo olivaceus (Linnaeus, 1766) & $\mathrm{Fr}$ & & 11 & 2 & 11 & 15 & 47 & \\
\hline & Hylophilus poicilotis (Temminck, 1822) & $\mathrm{Fr}$ & 1 & & 2 & 3 & & 3 & \\
\hline TROGLODYTIDAE & Troglodytes musculus (Naumann, 1823) & $\mathrm{OA}$ & & & 1 & & 1 & 1 & 1 \\
\hline \multirow[t]{4}{*}{ TURDIDAE } & Turdus rufiventris (Vieillot, 1818) & $\mathrm{OA}$ & 11 & 27 & 13 & 8 & 17 & 22 & 5 \\
\hline & Turdus amaurochalinus (Cabanis, 1850) & $\mathrm{Fr}$ & 6 & 16 & 3 & 2 & 3 & 9 & 3 \\
\hline & Turdus subalaris Seebohm, 1887) & $\mathrm{Fr}$ & 1 & & & 1 & & 3 & \\
\hline & Turdus albicollis (Vieillot, 1818) & $\mathrm{Fr}$ & 1 & 6 & 5 & 1 & 3 & 6 & 6 \\
\hline \multirow[t]{9}{*}{ THRAUPIDAE } & Saltator similis (d'Orbigny \& Lafresnaye, 1837) & $\mathrm{Fr}$ & 5 & 1 & 4 & 6 & 7 & 1 & \\
\hline & Saltator maxillosus (Cabanis, 1851) & $\mathrm{Fr}$ & 4 & 1 & & & & & 1 \\
\hline & Pyrrhocoma ruficeps (Strickland, 1844) & $\mathrm{Bb}$ & 2 & 2 & 8 & 1 & 4 & 3 & \\
\hline & Tachyphonus coronatus (Vieillot, 1822) & $\mathrm{Fr}$ & 2 & & 2 & & 3 & & \\
\hline & Lanio melanops (Vieillot, 1818) & $\mathrm{Fr}$ & & 1 & & & & & \\
\hline & Tangara sayaca (Linnaeus, 1766) & $\mathrm{Fr}$ & & & & 1 & & 3 & \\
\hline & Tangara preciosa (Cabanis, 1850) & $\mathrm{Fr}$ & & & & & & 1 & \\
\hline & Stephanophorus diadematus (Temminck, 1823) & $\mathrm{Fr}$ & 1 & 1 & 6 & 3 & 5 & 2 & 2 \\
\hline & Pipraeidea melanonota (Vieillot, 1819) & $\mathrm{Fr}$ & & & & 3 & 1 & 1 & \\
\hline \multirow[t]{6}{*}{ EMBERIZIDAE } & Zonotrichia capensis (Statius Müller, 1776) & OA & 5 & 9 & 4 & 8 & 53 & 133 & 10 \\
\hline & Haplospiza unicolor (Cabanis, 1851) & $\mathrm{Bb}$ & 19 & 11 & 3 & 13 & 72 & 114 & 3 \\
\hline & Poospiza thoracica (Nordmann, 1835) & $\mathrm{Fr}$ & & 2 & & & & & \\
\hline & Poospiza cabanisi (Nordmann, 1835) & $\mathrm{Fr}$ & 8 & 7 & 10 & 8 & 20 & 71 & 4 \\
\hline & Volatinia jacarina (Linnaeus, 1766) & $\mathrm{OA}$ & & & 1 & & 15 & 145 & 1 \\
\hline & Sporophila caerulescens (Vieillot, 1823) & $\mathrm{OA}$ & 1 & 1 & 1 & 1 & 2 & 3 & 5 \\
\hline CARDINALIDAE & Cyanoloxia brissonii (Lichtenstein, 1823) & $\mathrm{OA}$ & & 1 & & 1 & 1 & 1 & 1 \\
\hline \multirow[t]{4}{*}{ PARULIDAE } & Parula pitiayumi (Vieillot, 1817) & $\mathrm{Fr}$ & 1 & 1 & 1 & & 7 & 1 & 1 \\
\hline & Geothlypis aequinoctialis (Gmelin, 1789) & $\mathrm{Fr}$ & 1 & & & & & & \\
\hline & Basileuterus culicivorus (Deppe, 1830) & $\mathrm{Fr}$ & 7 & 4 & 8 & 3 & 7 & 6 & 1 \\
\hline & Basileuterus leucoblepharus (Vieillot, 1817) & $\mathrm{Fr}$ & 6 & 5 & 8 & 8 & 10 & 14 & \\
\hline ICTERIDAE & Molothrus bonariensis (Gmelin, 1789) & $\mathrm{OA}$ & & & & & 1 & & \\
\hline FRINGILLIDAE & Sporagra magellanica (Vieillot, 1805) & OA & 8 & 7 & 7 & 2 & & 12 & \\
\hline
\end{tabular}

Recebido em 21 de maio de 2012. Aceito em 21 de dezembro de 2012. ISSN 0073-4721

Artigo disponível em: www.scielo.br/isz 